
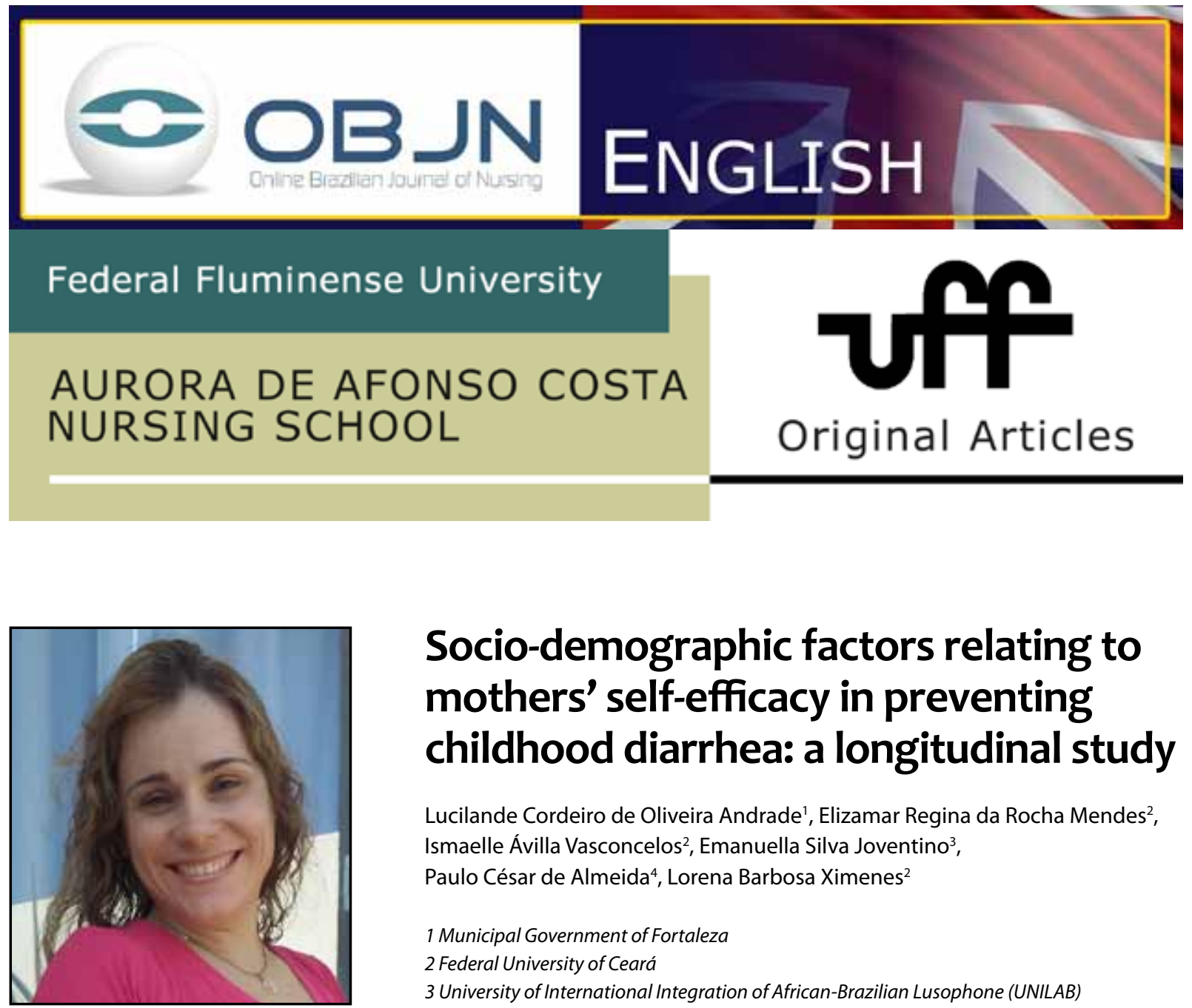

\title{
Socio-demographic factors relating to mothers' self-efficacy in preventing childhood diarrhea: a longitudinal study
}

\author{
Lucilande Cordeiro de Oliveira Andrade ${ }^{1}$, Elizamar Regina da Rocha Mendes² \\ Ismaelle Ávilla Vasconcelos², Emanuella Silva Joventino ${ }^{3}$, \\ Paulo César de Almeida ${ }^{4}$, Lorena Barbosa Ximenes ${ }^{2}$ \\ 1 Municipal Government of Fortaleza \\ 2 Federal University of Ceará \\ 3 University of International Integration of African-Brazilian Lusophone (UNILAB) \\ 4 Ceará State University
}

\begin{abstract}
Aim: To determine the links between socio-demographic data of mothers living in at-risk micro areas and their self-efficacy in preventing childhood diarrhea. Methods: This is a longitudinal study conducted in Fortaleza, with 90 mothers of children under five years of age. Data collection was performed through the use of the Maternal Self-efficacy Scale for Childhood Diarrhea Prevention (EADPI) and by telephone. Data were analyzed by chi-square tests and likelihood ratio. Results: Statistical significance in self-efficacy levels was found within the following variables: aged between 15 and $29(\rho<0.001)$; married $(p=0.035)$; consensual union ( $\rho=0.039)$; single ( $p=0.033)$; more than five years of schooling $(\rho<0.001)$; per capita income lower than $R \$ 169.50$ ( $\rho<0.001)$; per capita income more than $R \$ 169.50$ ( $\rho<0.001)$; housewife $(\rho<0.001)$; other occupations $(\rho<0.001)$; and number of children $(\rho<0.001)$. Conclusion: When nurses use the EAPDI they can monitor mothers' self-efficacy and use these results in conjunction with the socio-economic conditions of mothers that influence the occurrence of diarrhea in order to intervene with educational activities.

Descriptors: Childhood Diarrhea; Self-Efficacy; Social Conditions; Health Promotion; Nursing.
\end{abstract}




\section{INTRODUCTION}

Childhood diarrhea is a common manifestation of infectious and parasitic diseases, caused by numerous etiological agents and is characterized by episodes of mollified or watery stools over a 24-hour period ${ }^{(1)}$. This disease is a serious public health problem and it is among the leading causes of medical consultations, hospitalizations, medical emergencies, and mortality in children under five years of age ${ }^{(1)}$.

The factors that determine the occurrence of childhood diarrhea are multiple and they involve, directly or indirectly, environmental, socioeconomic, cultural, and behavioral aspects, and they may vary depending on the population studied $^{(2)}$. Therefore, these variables need to be investigated in different contexts so that nurses can intervene in a more direct way with actions that are consistent with the targeted population.

It is noteworthy that infant diarrheal disease is the best example of a grievance in which maternal knowledge and attitude toward the proper management of childhood diarrhea effectively influence the reduction of the disease's complications. However, it is known that simply having such information does not guarantee the promotion of children's health. It is necessary for mothers to feel they are able to incorporate these practices in their daily lives ${ }^{(3)}$.

In this context we can evaluate the concept of self-efficacy, which is an individual's ability to judge him/herself capable of successfully performing a given action ${ }^{(4)}$ in view of the difference between having competencies and being able to execute them effectively. Therefore, success in shifting maternal attitudes in order to prevent childhood diarrhea requires strong confidence in mothers of their ability to exercise such behaviors. In this sense, the theory of self-efficacy becomes a concept that should be compared to nursing actions, as it covers aspects that can influence behavioral changes that promote good health ${ }^{(5)}$.

It should be emphasized that reliable and validated psychometric scales should be used to assess the construct mentioned, including the Maternal Self-efficacy Scale for Childhood Diarrhea Prevention (EAPDI), built and validated in Brazil with 448 mothers of children in early childhood living in Fortaleza/CE ${ }^{(3,8)}$. The EAPDI allows health professionals, including nurses, to be aware of the areas in which mothers have lower levels of self-efficacy. This knowledge contributes directly to the implementation of educational strategies used to prevent the risk factors that promote the occurrence of childhood diarrhea. In addition, evaluation through the scale allows individualized care to be given to the child, especially with regard to the fields of EAPDI (Family and general hygiene, and eating habits), taking into account the particularities of each family, and the evaluation may contribute to the elevation of levels of maternal self-efficacy in preventing childhood diarrhea.

Given the above, this study aimed to assess the links between the socio-demographic data of mothers living in at-risk micro areas and their self-efficacy in preventing childhood diarrhea.

\section{METHOD}

This is a descriptive, analytical, and longitudinal study carried out through the monitoring of the families and data collection at three time points over a period of three months. The research was conducted in a Primary Healthcare Unit (PHU), integrated into the Regional Executive Secretariat V (RES V) of Fortaleza, which includes 41,971 children under the age of five, which corresponds to $24.86 \%$ of the city's population. The choice of RES $V$ was justified by its representativeness in the most risky socioeconomic indicators: high population density, lower per capita income and lowest Human Development Index (HDI). Moreover, this is a micro area of risk 
as it has a needy profile for basic social devices, such as adequate housing, basic sanitation, education, employment, and income. In 2012, RESV showed the highest levels of reported cases of diarrhea: 5,726 occurrences, of which 2,172 were reported in children aged one to four years ${ }^{(6,7)}$.

Sampling was made by convenience and the participating mothers met the following inclusion criteria: at least one child under the age of five years accompanied by a mother in the selected PHUs. The exclusion criteria were mothers who presented any cognitive limitations that would make them unable to respond to the instruments used, and mothers who had no phone number. The discontinuity criteria were mothers' waiver when it came to participating in the study after the beginning of the data collection; a change of phone number during the study without prior notice given to researchers; and the death of the mother or the child during the course of the study.

Considering the aspects mentioned above, the mothers were selected by means of the fulfillment of the A form - a form developed by the Health Ministry and completed by community health workers (CHWs). These mothers had previously been invited to attend the PHU on certain days, according to their availability.

Thus, the study sample was calculated from the formula to estimate the population average $\mathrm{n}=(\mathrm{Z} . \mathrm{a} / \mathrm{e})^{2}$, considering $\mathrm{Z}=1.96 ; \mathrm{a}= \pm 7.40$ (standard deviation of the variable studied - Items EAPDI) ${ }^{(8),}$ and a sampling error of $2 \%$. The initial sample was composed of 53 mothers of children under five years of age, so we opted to add a security percentage rate of $41 \%$ to that total for possible losses during the telephone follow-up period. Consequently we obtained a final sample of 90 mothers, which means that data collection has brought the following results: 90 mothers (PHU) participated at the initial moment (M0); 82 mothers participated at moment one (M1);
80 mothers took part at moment two (M2); and 79 mothers participated at moment three (M3). These figures take into account the sample losses and phone number switches without prior notice given to researchers that occurred during the study.

Data collection occurred from April to July 2013 in two stages. In the first stage, interviews with the mothers were performed at the unit using the EAPDI, as well as the completion of a form that asked for information about the socio-demographic aspects of each family (moment 0 ). The second stage consisted of the monitoring of maternal self-efficacy by means of EAPDI beginning with the monthly telephone contact that occurred during the three months of the study (moments 1, 2, and 3). Given that the construct of self-efficacy is a modifiable factor over time, this makes it necessary to investigate the evolution of the scores in the EAPDI of these mothers.

The EAPDI is a composite scale of 24 items, two domains (family hygiene, with 15 items, and food/general practices, including nine items), with a high Content Validity Index (CVI=0.96), and Cronbach's alpha (0.84), whose response options on a Likert scale range from one (strongly disagree) to five (strongly agree). It is possible to choose only one option in each item. Thus, the total scores of the scale can range from 24 to 120 points ${ }^{(8)}$.

Data were analyzed using the Statistical Package for Social Sciences (SPSS) (version 20.0). We used descriptive and inferential statistics by means of the chi-square test and the maximum likelihood, establishing the level of significance at $5 \%(p<0.05)$ and the confidence interval at $95 \%$. It is noteworthy that the ethical aspects related to Resolution No. 466/2012 of the National Health Council were followed, with approval by the Ethics Committee in Research of the Federal University of Ceará under opinion No. 106/12. 
All participants signed the Terms of Informed Consent.

\section{RESULTS}

As for the socio-demographic characteristics, we can observe that, among the 90 mothers involved in the study, their ages range from 15 to 58 years with an average of 29 years (SD \pm 7.5 ). The predominant groups were as follows: age group 15 to 29 years ( $\mathrm{N}=48 ; 53.3 \%)$; consensual union $(\mathrm{N}=33 ; 36.7 \%)$; five to eight years of schooling ( $\mathrm{N}=49 ; 54.4 \%)$; and mothers who are housewives ( $\mathrm{N}=70 ; 77.8 \%)$.

It should be noted that the per capita monthly income was lower than $\mathrm{R} \$ 169.50$, although the minimum wage was $R \$ 678.00$ at the time of the study), and there was an average of four to five people living in the same household ( $\mathrm{N}=42$; 46.7\%). Most mothers had three to eight children $(n=37 ; 48.1 \%)$, and the majority of these children were male ( $\mathrm{N}=47 ; 52.2 \%)$.

In Table 1, we analyze maternal self-efficacy in preventing childhood diarrhea and socio-demographic variables, comparing the averages for EAPDI in the three months of follow up (M0-initial; M1, M2, and M3). Statistical significance between the averages of EAPDI scores was observed in the four moments of monitoring, and they presented the following variables $(p<0.05)$ : maternal age; marital status; education (years of study $\geq 5$ ); occupation; per capita income; number of children; and child's sex.

Looking at Graph 1, we can see that families with up to $1 / 4$ of the minimum wage per capita (extremely poor families) and families with $1 / 4$ to $1 / 2$ of the minimum wage per capita (absolute poverty) showed variation in EAPDI scores, and the result grew from $\mathrm{M} 0$ to $\mathrm{M} 1$ and decreased from $\mathrm{M} 2$ to $\mathrm{M} 3$.

It was found that the scores of mothers with a per capita income between $1 / 4$ and $1 / 2$ of the minimum wage increased significantly between M0 and M1 (13.6 scores) and obtained a score balance of 8.6 from M0 to M3. However, mothers with a per capita income lower than or equal to $1 / 4$ of the minimum wage showed an increase of 5.4 scores in $\mathrm{MO}$ and $\mathrm{M} 1$ and achieved 6.4 scores from M0 to M3; that is, they had lower scores when compared to the previous group with respect to maternal self-efficacy levels of preventing childhood diarrhea.

Graph 1 - Average scores on EAPDI regarding the per capita income according to the analyzed time. Fortaleza, 2013.

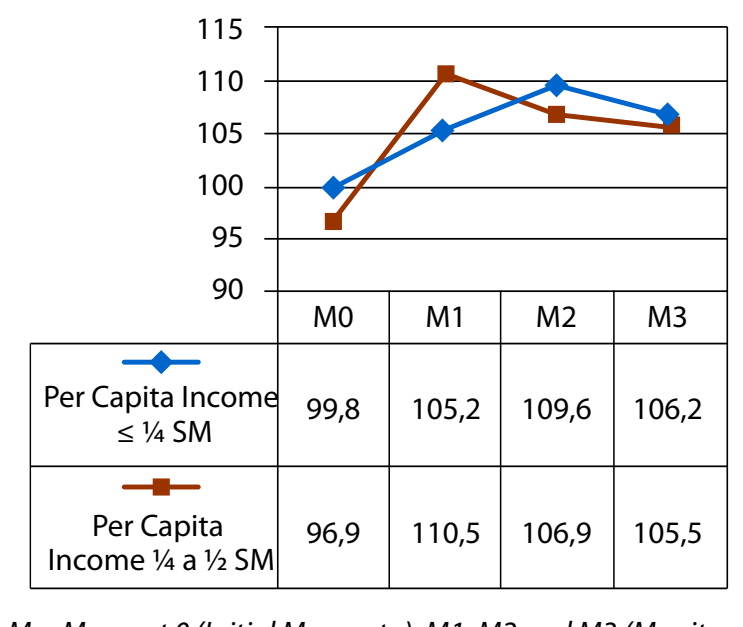

M = Moment 0 (Initial Momento); M1, M2 and M3 (Monitoring by phone)

\section{DISCUSSION}

The socio-demographic variables can be directly associated with children diarrhea as risk or protection factors. Thus, we observed that low maternal age and reduced schooling featured in several studies as risk factors for children's health - especially mothers' education, since it represents both their individual and their families'socio-economic condition, and it is related to the cultural and behavioral profile in this context in addition to being linked to the healthcare of families and children ${ }^{(9,10)}$. 
Table 1 - Comparison of the averages of EAPDI scores during follow-up, according to sociodemographic variables. Fortaleza, 2013.

\begin{tabular}{|c|c|c|c|c|c|c|c|c|c|c|c|}
\hline \multirow{3}{*}{ VARIABLES } & \multicolumn{11}{|c|}{ EAPDI Scores } \\
\hline & \multirow{2}{*}{$\mathbf{N}$} & \multirow{2}{*}{$\%$} & \multicolumn{2}{|c|}{ MOMENT 0} & \multicolumn{2}{|c|}{ MOMENT 1} & \multicolumn{2}{|c|}{ MOMENT 2} & \multicolumn{2}{|c|}{ MOMENT 3} & \multirow{2}{*}{$\mathbf{p}$} \\
\hline & & & $M$ & \pm ASE & $M$ & \pm ASE & $M$ & \pm ASE & $M$ & \pm ASE & \\
\hline \multicolumn{12}{|l|}{ Age } \\
\hline $15-29$ & 48 & 53,3 & 99,08 & $\pm 1,35$ & 105,53 & $\pm 1,47$ & 105,5 & $\pm 1,50$ & 105,44 & $\pm 1,66$ & $<0,001$ \\
\hline $30-58$ & 42 & 46,7 & 103,36 & $\pm 1,54$ & 106,92 & $\pm 1,76$ & 107,95 & $\pm 1,70$ & 107,39 & $\pm 1,74$ & $<0,001$ \\
\hline \multicolumn{12}{|l|}{ Marital Status } \\
\hline Married & 23 & 25,5 & 102,96 & $\pm 2,38$ & 103,95 & $\pm 2,66$ & 104,6 & $\pm 2,34$ & 104,7 & $\pm 2,45$ & 0,035 \\
\hline Consensual union & 33 & 36,7 & 99,91 & $\pm 1,67$ & 105,8 & $\pm 1,84$ & 104,62 & $\pm 1,89$ & 105,62 & $\pm 2,11$ & 0,039 \\
\hline $\begin{array}{l}\text { Single / widowed / } \\
\text { divorced }\end{array}$ & 34 & 37,8 & 100,94 & $\pm 1,54$ & 107,97 & $\pm 1,64$ & 109,9 & $\pm 1,64$ & 108,23 & $\pm 1,80$ & 0,033 \\
\hline \multicolumn{12}{|l|}{ Years of study } \\
\hline $01 / \mathrm{Apr}$ & 7 & 7,8 & 100,43 & $\pm 4,87$ & 103,67 & $\pm 3,77$ & 103,33 & $\pm 3,51$ & 100,67 & $\pm 4,58$ & 0,905 \\
\hline 05/Aug & 49 & 54,4 & 101,29 & $\pm 1,38$ & 105,57 & $\pm 1,62$ & 106,18 & $\pm 1,57$ & 105,82 & $\pm 1,57$ & $<0,001$ \\
\hline 09/nov & 34 & 37,8 & 100,91 & $\pm 1,66$ & 107,67 & $\pm 1,72$ & 108,1 & $\pm 1,79$ & 108,5 & $\pm 2,01$ & $<0,001$ \\
\hline \multicolumn{12}{|l|}{ Profession } \\
\hline Housewife & 70 & 77,8 & 101,2 & $\pm 1,17$ & 106,51 & $\pm 1,30$ & 107,77 & $\pm 1,26$ & 107,52 & $\pm 1,33$ & $<0,001$ \\
\hline Others & 20 & 22,2 & 100,65 & $\pm 2,30$ & 105,16 & $\pm 2,35$ & 103,11 & $\pm 2,37$ & 102,79 & $\pm 2,59$ & $<0,001$ \\
\hline \multicolumn{12}{|c|}{ Per capita income $(\mathbf{R} \$)$} \\
\hline$\leq 1 / 4 \mathrm{SM}$ & & & 99,81 & $\pm 1,04$ & 105,24 & $\pm 1,11$ & 109,69 & $\pm 1,25$ & 106,29 & $\pm 1,56$ & $<0,001$ \\
\hline$>1 / 4 \mathrm{SM}$ & & & 96,92 & $\pm 2,13$ & 110,5 & $\pm 1,51$ & 106,44 & $\pm 2,27$ & 105,59 & $\pm 2,06$ & $<0,001$ \\
\hline \multicolumn{12}{|c|}{ Number of persons living in the household } \\
\hline 2 a 3 & 28 & 31,1 & 96,78 & $\pm 1,52$ & 107,47 & $\pm 1,46$ & 109,8 & $\pm 2,36$ & 103,22 & $\pm 2,45$ & $<0,001$ \\
\hline 4 a 5 & 42 & 46,6 & 102,72 & $\pm 1,56$ & 107,89 & $\pm 1,54$ & 108,57 & $\pm 1,48$ & 108,85 & $\pm 1,67$ & 0,024 \\
\hline 6 a 11 & 20 & 2,3 & 97,08 & $\pm 1,62$ & 103 & $\pm 1,83$ & 106,67 & $\pm 2,70$ & 101,57 & $\pm 2,19$ & 0,011 \\
\hline \multicolumn{12}{|c|}{ Number of children } \\
\hline 1 & 30 & 33,3 & 99,07 & $\pm 1,85$ & 105,24 & $\pm 1,90$ & 106,46 & $\pm 1,66$ & 106,25 & $\pm 2,09$ & 0,001 \\
\hline 2 & 23 & 25,6 & 103,52 & $\pm 1,76$ & 112,47 & $\pm 2,03$ & 110,79 & $\pm 2,39$ & 111,18 & $\pm 2,43$ & 0,047 \\
\hline 03/Aug & 37 & 41,1 & 101,19 & $\pm 1,68$ & 103,5 & $\pm 1,68$ & 104,45 & $\pm 1,82$ & 104,09 & $\pm 1,74$ & $<0,001$ \\
\hline \multicolumn{12}{|l|}{ Child sex } \\
\hline Male & 47 & 52,2 & 100,45 & $\pm 1,54$ & 105,87 & $\pm 1,54$ & 105,2 & $\pm 1,46$ & 105,18 & $\pm 1,67$ & $<0,001$ \\
\hline Female & 43 & 47,8 & 101,77 & $\pm 1,38$ & 106,59 & $\pm 1,69$ & 108,54 & $\pm 1,73$ & 107,89 & $\pm 1,71$ & $<0,001$ \\
\hline
\end{tabular}

ASE $=$ Average Standard Error

$M=$ Moment 0 (Initial Momento); M1, M2 and M3 (Monitoring by phone)

As we intended to verify the behavior of mothers' self-efficacy over time in this study, we observed that both adolescent and young adult mothers represented a progressive increase in the EAPDI scores, despite the fact that the self-efficacy scores of older mothers prevailed over the scores of young mothers as the investigation continued. A study in Fortaleza investigating early weaning corroborated this finding by demonstrating that low maternal age may be related to an inadequate interpretation and assimilation of knowledge related to childcare ${ }^{(11)}$. Other studies have shown similar results in terms of low maternal age ${ }^{(12)}$.

It should be noted that the greater the number of positive experiences mothers have, the greater self-efficacy can be perceived and mediated by their sources, mainly the source of personal self-efficacy, or vicarious and molding experiences $^{(5)}$. 
Regarding marital status, the variable showed a significant relation with the scores of the scale, demonstrating that father's support contributes to the improved care provided for children. Thus, in this analysis we can see that between the civil status variables only, married mothers showed a progressive increase in self-efficacy over time.

A study involving 50 women in Pacatuba/ CE found that marital statuses such as marriage and common-law marriage have a direct influence on maternal self-efficacy in terms of breastfeeding ${ }^{(13)}$. Even with the statistically significant association between maternal self-efficacy mean scores in preventing childhood diarrhea and marital status (marriage and common-law marriage), it was observed that single mothers, widows, or divorcees also showed statistical significance in terms of the average scores for preventing childhood diarrhea. Thus, it can be inferred that maternal self-efficacy may be influenced by other sources of maternal confidence, verbal persuasion, and vicarious experiences, which are not necessarily related to the father's presence.

A cross-sectional study involving 448 mothers of children under five years of age in Singapore has shown that the fact that most of these women are married or live in a consensual union was not associated with their ability to care for children in terms of the prevention and treatment of diarrhea ${ }^{(14)}$.

For example, it can be seen that among the surveyed mothers, those who were widowed, divorced, or single had the highest self-efficacy scores, especially in moments $M 1, M 2$, and M3. One can also infer that those mothers who cannot count on their partners' daily help are alone in taking on most of the childcare responsibilities. This fact can raise their self-confidence in terms of the care they provide for their children.
Although this study observed statistical significance both in terms of mothers who work in the household and those working outside the home, some studies have shown the influence of maternal occupation on children's health, leading to the belief that women who have occupations outside the home have less time available, which can influence the quality of the maternal care they provide for their children ${ }^{(15)}$.

However, this study showed no association between mothers who work in the household and a greater self-efficacy in preventing childhood diarrhea. We can also observe that mothers' self-efficacy was not influenced by the number of residents in the home $(p=0.154)$, by the child's gender $(p=0.062)$, or by the number of children $(p=0.861)^{(16)}$.

The per capita income is a relevant item with regard to the socio-economic status of a family and is, therefore, a social determinant of health that has a direct impact on individuals ${ }^{(17)}$. Thus, it can be seen in this study that the self-efficacy scores for preventing childhood diarrhea of mothers with a per capita income $>1 / 4$ of the minimum wage increased significantly between M0 and M1 (13.6 scores), while they obtained a score balance of 8.6 between $\mathrm{M} 0$ and M3. On the other hand, the scores presented by the group of mothers living in extreme poverty, despite increasing 5.4 scores during $\mathrm{M} 0$ to $\mathrm{M} 1$ and 6.4 scores between $M 0$ to $M 3$, were still lower than the group with the highest per capita income.

We note that other reviews have corroborated these findings that show that low family income has a significant correlation with infectious and parasitic diseases, particularly diarrheal diseases in children aged five years or younger. This is because children from poor families have a greater vulnerability and constant exposure to susceptibility factors for the disease: poor sanitation; inadequate use of water; agglomerations; and pollution. There is also the 
fact that their caregivers are less likely to adopt diarrhea prevention behaviors as they possibly have lower levels of self-efficacy ${ }^{(18,19)}$.

Regarding the variable of number of children, it was observed that most of the women interviewed had three to eight children $(\mathrm{N}=37$; $41.1 \%)$, followed by those who had only one child ( $\mathrm{N}=30 ; 33.3 \%)$, and, finally, mothers with two children ( $\mathrm{N}=23 ; 25.6 \%)$. Therefore, the three variables showed representative statistical significance. It should be noted that mothers with two or more children scored higher on the self-efficacy scale in preventing childhood diarrhea. These data agree with the research conducted with 448 mothers, since the study showed that the greater the number of children, the greater the chance of successful experiences in terms of childcare, and, in this case, in terms of the handling of diarrhea, which could be considered positive in this study ${ }^{(8)}$.

Another finding revealed in Graph 1 is the question of temporality and its relation to the maintenance of maternal self-efficacy, since there was clear oscillation in terms of the average scores for the prevention of childhood diarrhea in the four moments of monitoring for the two per capita income groups, especially between $M 2$ to $M 3$, where there was a decrease.

Self-efficacy represents the belief that people have in transforming their actions. This parameter influences the way people deal with events that affect their lives and how they determine personal decisions as the beginnings of coping behavior, along with the amount of time that they will take to overcome obstacles and adverse experiences, as well as the amount of effort required for such behavior ${ }^{(5)}$.

Even if the participants join a population devoid of any resources, and even if social problems can contribute to minimizing maternal self-efficacy with regard to infant diarrhea, we highlight the need to find alternatives so that nurses can implement strategies for the promotion of children's health by their mothers in the best possible way, despite the adverse conditions.

Thus, the assessment of maternal self-efficacy by the nurses of the Family Health Strategy, particularly during routine visits, allows for identification of the levels of this construct. Therefore, when these professionals identify mothers as having low levels of self-efficacy (as it is a negative predictor for health promotion), they will be able to intervene in order to raise maternal self-efficacy scores in order to prevent childhood diarrhea and consequently reduce related child morbidity and mortality. To this end, nurses can make use of the four sources of self-efficacy (personal experience; vicarious experience; verbal persuasion; and physiological/emotional states) for the implementation of specific strategies to strengthen the effect of these sources ${ }^{(20)}$.

\section{CONCLUSION}

The study results showed that there was a statistically significant association between the level of maternal self-efficacy in preventing childhood diarrhea and several factors related to environmental, socio-economic, cultural, and behavioral conditions of the participating mothers.

Some factors, such as low maternal age, low education, low income, number of children, and paternal absence, may influence maternal self-efficacy and generate some insecurity in childcare, and these factors are associated with the development of diarrheal episodes. This suggests the need for promoting maternal empowerment as well as behavioral changes in order to promote the health of the children involved. 
Thus, nurses should identify maternal self-efficacy through the use of the EAPDI scale for, firstly, using the prevention of childhood diarrhea as a tool in child healthcare, and secondly, as a way of promoting mothers' self-efficacy in preventing diarrhea, carried out through health educational strategies and the encouragement of mothers so that they feel more capable of preventing this disease in their children.

The research presented a limitation in the difficulty encountered in re-establishing phone contact during the monitoring of some mothers in the study, and also by the fact that this is a unicentric study. Moreover, we recommend future studies be conducted over a longer monitoring period.

\section{REFERENCES}

1. Oliveira TCR, Latorre MRDO. Trends in hospital admission and infant mortality from diarrhea: Brazil, 1995-2005. Rev. Saúde Pública. 2010 [Cited 2013 Jan 1] 44(1): 102-1.Available from: http:// www.scielo.br/scielo.php?script=sci_arttext\&pi d=S003489102010000100011. doi:http://dx.doi. org/10.1590/S0034-89102010000100011

2. Ministério da Saúde (Brasil). Secretaria de Vigilância em Saúde. Departamento de Vigilância Epidemiológica. Doenças infecciosas e parasitárias: Guia de bolso / Ministério da Saúde, Secretaria de Vigilância em Saúde, Departamento de Vigilância Epidemiológica. 8. ed. Brasília : Ministério da Saúde; 2010. Available from:http://bvsms. saude.gov.br/bvs/publicacoes/doencas_infecciosas_parasitaria_guia_bolso.pdf

3. Joventino ES. Validação aparente e de conteúdo da escala de autoeficácia materna para prevenção da diarreia infantil. Rev. Latino-Am. Enfermagem. 2013 [Cited 2013 Jan 1] 21(1).Available from:http://www.revistas.usp.br/rlae/article/ viewFile/52964/56997.

4. Bandura A. Toward a Psychology of Human Agency. Perspec Psychol Sci. 2006 [Cited 2013 Jan 1] 1(2):164-80. Available from: http://web. stanford.edu/dept/psychology/bandura/pajares/ Bandura2006PPS.pdf

5. Bandura A. Self-efficacy: toward a unifying theory of behavioral change. Psychol. Rev. 1977 [Cited 2013 Jan 1] 84(2): 191-215.

6. Secretaria Municipal de Saúde. Célula de Vigilância Epidemiológica/CIEVS/SIMDA. Consolidado das notificações de casos de diarreia aguda por Secretaria Executiva Regional. Fortaleza, 2013 [Cited 2013 Jan 21]. Available from: http://tc1. sms.fortaleza.ce.gov.br/simda/notifica/graficos erano $=2012 \&$ ser $=\&$ agravo $=$ A09.

7. Instituto Brasileiro de Geografia E Estatística (IBGE). Distribuição da população por sexo, segundo os grupos de idade - Censo 2010[Cited 2013 Apr6]. Available from: http:// www.censo2010.ibge.gov.br/sinopse/index. php?dados=26\&uf=23\#topo_piramide.

8. Joventino ES, Ximenes LB, Almeida PC, Oria MOB. The Maternal Self-efficacy Scale for Preventing Early Childhood Diarrhea: Validity and Reliability. Public Health Nursing. 2013 [Cited Apr 21]; 30(2):150-8. Available from: http://www.objnursing.uff.br/index.php/nursing/article/view/3961/ html. doi: 10.1111/j.1525-1446.2012.01042.x.

9. Barros MBA, Zanchetta LM, Moura EC, Malta DC. Auto-avaliação da saúde e fatores associados, Brasil, 2006. Rev. Saúde Pública. 2009 [Cited Apr 21] 43 Suppl 2: 27-37.Available from: http:// www.scielo.br/scielo.php?script=sci_arttext\&pid =S0034-89102009000900005. doi:http://dx.doi. org/10.1590/S0034-89102009000900005

10. Maia LTS, Souza WV, Mendes ACG. Differences in risk factors for infant mortality in five Brazilian cities: a case-control study based on the Mortality Information System and Information System on Live Births. Cad.Saúde Pública. [internet] 2012 [Cited Apr 21] 28(11). Available from: http://www.scielo.br/ scielo.php?script=sci_arttext\&pid=S0102-311X2012001100016. doi:http://dx.doi. org/10.1590/S0102-311X2012001100016.

11. Oliveira JS, Joventino ES, Dodt RCM, Veras JEGLF, Ximenes LB. Factors associated with early weaning among multiparous. Rev. RENE. [internet] 2010 [Cited Apr 21]; 11(4):95-102. Available from: http://www.repositorio.ufc.br/bitstream/ riufc/4186/1/2010_art_esjoventino.pdf 
12. Andrade LCO, Santos MS, Aires JS, Joventino ES, Dodt RCM, Ximenes LB. New mothers' knowledge about hygiene for new-borns. Cogitare Enfermagem. 2012 [Cited 2014 Apr 21] 17(10):99-105.Availablefrom: http://ojs.c3sl.ufpr. br/ojs2/index.php/cogitare/article/view/26381. doi: http://dx.doi.org/10.5380\%2Fce.v17i1.26381

13. Uchoa JL, Oliveira EKF, Gomes ALA et al. Influence on conditions of health of the newborn about the maternal self-efficacy in breastfeed. Rev enferm UFPE on line.[internet] 2012 [Cited 2014 Apr 21]; 6(8):1798-804. Availablefrom: http://www.revista. ufpe.br/revistaenfermagem/index.php/revista/article/view/3024/pdf_1355. doi: 10.5205/ reuol.2931-23598-1-LE.0608201208

14. Joventino ES, Coutinho RG, Bezerra KC, Almeida PC, Oriá MOB, Ximenes LB. Self-effectiveness in preventing diarrhea and child care: a transversal study. Online braz j nurs [Internet]. 2013 [Cited Apr 21]; 12(2): 295-306. Available from: http://www.objnursing.uff.br/index.php/ nursing/article/view/3961.doi: http://dx.doi. org/10.5935/1676-4285.20133961

15. Pantenburg B, Ochoa TJ, Ecker L, Ruiz J. Feeding of young children during diarrhea: caregivers' intended practices and perceptions. Am JTrop Med Hyg. [internet] 2014 [Cited Jan 23]; 91(3):555-62. Available from: http://www.ncbi.nlm.nih.gov/ pubmed/25092824.

16. Joventino ES, Bezerra KC, Coutinho RG, Almeida PC, Oriá MOB, Ximenes LB.Socio-demographic and healthcare conditions regarding maternal self-sufficiency/effectiveness concerning preventing diarrhea during childhood. Rev. salud pública.[internet] 2013 [Cited 2014 Apr 21]; 15(4): 542-554. Available from: http://www.ncbi.nlm. nih.gov/pubmed/25124126

17. Mendes EV. Health care networks. Ciência \& Saúde Coletiva. 2010 [CitedApr 21]15(5):2297-2305. Availablefrom: http://www.scielo.br/pdf/csc/ v15n5/v15n5a05.pdf

18. Lopes TC, Chaves AFL, Joventino ES, Rocha RS, Castelo ARP, Oriá MOB. Avaliação da autoeficácia materna para a prevenção da diarreia infantil. Rev Rene. [internet] 2013; 14(6):1103-11. Available from: http://www.revistarene.ufc.br/revista/index.php/revista/article/viewFile/1247/pdf

19. Boccolini S, Boccolini CMM, Carvalho PL, Couto $M$, Oliveira MI. Exclusive breastfeeding and diarrhea hospitalization patterns between 1999 and 2008 in Brazilian State Capitals.Ciência \& Saúde Coletiva. 2012 [Cited Apr 11]17(7): 1857-1863.Availablefrom: http://www.scielo.br/scielo.php?pid=S1413$-81232012000700025 \& \mathrm{script}=\mathrm{sci}$ _art text. doi:http://dx.doi.org/10.1590/S141381232012000700025.

20. Uchôa JL, Gomes ALA, Joventino ES, Oriá MOB, Ximenes LB, Almeida PC. Antecedentes sociodemográficos e obstétricos na autoeficácia maternal em amamentar: estudo em painel. Online braz j nurs [Internet]. 2014 [Cited Jan 26] 13(4): 645-55. Available from:http://www.objnursing. uff.br/index.php/nursing/article/view/4708

All authors participated in the phases of this publication in one or more of the following steps, in According to the recommendations of the International Committee of Medical Journal Editors (ICMJE, 2013): (a) substantial involvement in the planning or preparation of the manuscript or in the collection, analysis or interpretation of data; (b) preparation of the manuscript or conducting critical revision of intellectual content; (c) approval of the versión submitted of this manuscript. All authors declare for the appropriate purposes that the responsibilities related to all aspects of the manuscript submitted to OBJN are yours. They ensure that issues related to the accuracy or integrity of any part of the article were properly investigated and resolved. Therefore, they exempt the OBJN of any participation whatsoever in any imbroglios concerning the content under consideration. All authors declare that they have no conflict of interest of financial or personal nature concerning this manuscript which may influence the writing and/or interpretation of the findings. This statement has been digitally signed by all authors as recommended by the ICMJE, whose model is available in http://www. objnursing.uff.br/normas/DUDE_eng_13-06-2013.pdf

Received: $11 / 19 / 2014$
Revised: $01 / 22 / 2015$
Approved: $01 / 31 / 2015$ 